Article

\title{
Gender Differences on Psychosocial Factors Affecting COVID-19 Preventive Behaviors
}

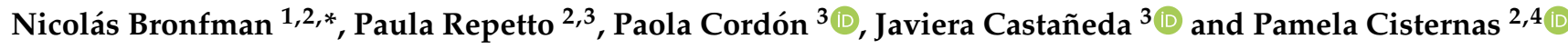 \\ 1 Engineering Sciences Department, Universidad Andres Bello, Santiago 7500973, Chile \\ 2 Research Center for Integrated Disaster Risk Management ANID/FONDAP/15110017, \\ Santiago 7820436, Chile; prepetto@uc.cl (P.R.); pccisternas@uc.cl (P.C.) \\ 3 Department of Psychology, Pontificia Universidad Católica de Chile, Santiago 7820436, Chile; \\ pcordon@uc.cl (P.C.); jvcastaneda@uc.cl (J.C.) \\ 4 Industrial and Systems Engineering Department, Pontificia Universidad Católica de Chile, \\ Santiago 7820436, Chile \\ * Correspondence: nbronfman@unab.cl
}

Citation: Bronfman, N.; Repetto, P.; Cordón, P.; Castañeda, J.; Cisternas, P. Gender Differences on Psychosocial Factors Affecting COVID-19 Preventive Behaviors. Sustainability 2021, 13, 6148. https://doi.org/ $10.3390 /$ su13116148

Academic Editors: Tehmina Khan and Pavithra Siriwardhane

Received: 14 April 2021

Accepted: 24 May 2021

Published: 30 May 2021

Publisher's Note: MDPI stays neutral with regard to jurisdictional claims in published maps and institutional affiliations.

Copyright: (c) 2021 by the authors. Licensee MDPI, Basel, Switzerland. This article is an open access article distributed under the terms and conditions of the Creative Commons Attribution (CC BY) license (https:// creativecommons.org/licenses/by/ $4.0 /)$.

\begin{abstract}
Previous studies have reported differences between men and women in the adoption of preventive behaviors against infectious diseases. This study aims to examine gender differences on a set of psychosocial factors shown to influence preventive behaviors against infectious diseases such as COVID-19. We conducted a web survey $(N=1.004)$ a few weeks after the end of the peak of the first wave of infections in Chile. The survey assessed participants' perception of risk and worry about the COVID-19 pandemic, confidence in the government's competence and integrity in dealing with the crisis, attribution of responsibility to various stakeholders, and adoption of preventive behaviors such as hygiene, distancing, and information-seeking. Our results confirm significant gender-based differences for both the psychosocial factors and the adoption of preventive behaviors. We conclude that women show a higher level of worry and fear of the pandemic and are keener to adopt preventive hygiene and social distancing behaviors. Similarly, participants report a low level of trust in government authorities, with women reporting the lowest trust level. The implications of these findings for the design of future risk communication strategies are discussed.
\end{abstract}

Keywords: gender; trust; worry; preventive behaviors; COVID-19

\section{Introduction}

Ever since the first cases of the COVID-19 disease caused by the SARS-CoV-2 virus emerged at the end of 2019, the virus has spread worldwide, causing a pandemic, claiming the lives of millions of people [1], and causing the worst economic recession since World War II [2]. Although the entire population is at risk, significant differences in case fatality rate have been reported by gender [3,4]. From a meta-analysis performed by Peckham et al. [5], the authors concluded that, compared to women, male patients are almost three times more likely to be admitted to the intensive care unit and more likely to die. Biological factors explain this difference (e.g., women have a better immune response than men [6]), as do behavioral and psychosocial risk factors such as smoking and lifestyle habits $[7,8]$.

Similarly, researchers have reported significant differences between women and men concerning perceptions of risk, worry, and fear of COVID-19. In general terms, previous studies have concluded that women report a higher risk perception regarding COVID-19 than men $[4,9,10]$ and more significant worry and fear $[4,11]$. On the other hand, reports have indicated that one of the main factors influencing risk perception and adopting preventive behaviors regarding COVID-19 is the trust that people have in the government's (or authorities) ability to respond to the pandemic [12]. Recent studies have concluded that non-compliance with preventive measures is strongly associated with insufficient 
trust in authorities [13]. Also, it is women who report the lowest levels of confidence in government leaders [14]. In a recent study using survey data from 57 countries, Rieger \& Wang [14] concluded that, on average, women tend to have less confidence in government authorities' actions in response to the COVID-19 pandemic. However, they also show that it is women who adopt cautionary behaviors at a higher rate.

Recent studies have reported differences in the adoption of preventive behaviors by gender. Overall, men tend to exhibit lower rates of preventive behavior adoption against infectious diseases such as COVID-19, including handwashing [15], social distancing [8], use of masks [16], and proactively seeking effective medical help [17,18]. On the other hand, reports also show that women are more knowledgeable about the disease symptoms and, therefore, seem to be more aware of the risk they face [19].

This phenomenon is not exclusive to the threat caused by COVID-19. Previous literature shows that gender is a relevant factor in the behavior, attitudes, and risk perception of other socio-natural hazards [20,21]. Bateman and Edwards [22] found that women are more likely than men to interpret warning signs as valid and are more aware of the signals of natural hazards. This awareness becomes more relevant when a family member is in danger, allowing them to be more responsive to warnings than their male counterparts. Women also exhibit a greater tendency for increased risk perception in the face of earthquakes [23] and floods [24], compared to men. Also, women are more likely than men to adopt preparedness measures [25] and participate in community preparedness activities [26].

Multiple explanations have been proposed for the differences in the adoption of preventive and response behaviors between men and women. Nevertheless, there seems to be a consensus that the cause is not an inherent characteristic but represents socially constructed gender differences $[9,22,27,28]$. For example, women tend to be given the caregiving role, they also tend to have a more acute perception of risk $[10,23]$, to be responsible for the household response plan, and to be the ones who execute it $[29,30]$.

Attribution of responsibility, another essential determinant of threat response, also varies between men and women. For example, in a Southern California resident survey, women attributed equal responsibility for seismic protection to internal stakeholder categories, such as family, and external stakeholders, such as authorities. In contrast, men attributed greater responsibility to internal stakeholders [31].

Previous studies have found that both the adoption of preventive behaviors against infectious diseases and the psychosocial factors that determine them vary between men and women. In this scenario, the study of the differences between women and men concerning the psychosocial factors motivating the adoption of preventive behaviors is essential for designing and implementing more effective risk communication strategies to combat not only the current COVID-19 pandemic but also potential future outbreaks. Thus, this study aims to examine gender differences in various psychosocial factors affecting COVID-19 preventive behaviors.

\section{Materials and Methods}

\subsection{Procedure and Participants}

All survey data was collected between 24 August and 8 November 2020, after the first peak (May-June 2020) of confirmed cases in Chile. A total of 1004 undergraduate and graduate students from three campuses of Universidad Andrés Bello in three of Chile's main cities completed the web survey: Concepción, Viña del Mar, and the capital, Santiago. We summarize the participants' socioeconomic characteristics ( $67.3 \%$ women) disaggregated by gender in Table 1.

Participants received an e-mail inviting them to participate in the study, which stated that participation was voluntary and would not receive any incentive for answering the survey. The average response time was $20 \mathrm{~min}$. The Ethics Committee of Universidad Andrés Bello approved all procedures used in this study. 
Table 1. Socioeconomic characteristics of female and male participants.

\begin{tabular}{|c|c|c|c|}
\hline \multirow{2}{*}{ Socioeconomic Characteristics } & All Sample & Female & Male \\
\hline & $(n=1.004)$ & $(n=676)$ & $(n=318)$ \\
\hline \multicolumn{4}{|l|}{ Age Group } \\
\hline $18-29$ & $78.3 \%$ & $81.8 \%$ & $70.8 \%$ \\
\hline $30-44$ & $18.1 \%$ & $15.8 \%$ & $23.2 \%$ \\
\hline $45-59$ & $3.6 \%$ & $2.4 \%$ & $6.0 \%$ \\
\hline$>60$ & $0.0 \%$ & $0.0 \%$ & $0.0 \%$ \\
\hline \multicolumn{4}{|l|}{ Partner Relationship } \\
\hline Married-partner & $15.8 \%$ & $13.9 \%$ & $20.1 \%$ \\
\hline Single-separated-divorced & $84.2 \%$ & $86.1 \%$ & $79.9 \%$ \\
\hline \multicolumn{4}{|l|}{ Monthly Family Income } \\
\hline$\$ 0-\$ 600,000$ & $31.7 \%$ & $33.6 \%$ & $27.0 \%$ \\
\hline$\$ 600,000-\$ 1,200,000$ & $27.8 \%$ & $28.1 \%$ & $27.1 \%$ \\
\hline$\$ 1,200,000-\$ 1,600,000$ & $14.8 \%$ & $15.3 \%$ & $14.5 \%$ \\
\hline$>\$ 1,600,000$ & $25.7 \%$ & $23.0 \%$ & $31.4 \%$ \\
\hline
\end{tabular}

\subsection{Materials}

This study used data obtained from a web survey that assessed preventive behaviors in a Chilean sample in response to the COVID-19 pandemic. We organized the survey into ten sections, and in this study, we only used seven of these.

Worry was assessed using six items adapted from previous studies [32,33], which were rated by participants using a 7-point Likert scale, from (1) "not at all worried" to (7) "very worried".

Risk perception in the face of the COVID-19 threat was measured using three items used and validated in previous studies in Chile [34], adapted from the survey by Lindell et al. (2009) [35]. Participants rated risk perception on a 7-point Likert scale, from (1) "no risk" to (7) "totally risky".

Table 2 presents the questions used to measure worry and risk perception.

Trust in the government was assessed through six items adapted from previous studies [36-38] (see Table 3): three to characterize integrity-based trust, and three for competence-based trust. Participants evaluated their trust in the government by indicating their level of agreement or disagreement with six statements using a 5-point Likert scale, from (1) "strongly disagree" to (5) "strongly agree".

In Table 4, we present the items used to evaluate the attribution of responsibility. Participants assessed the degree of responsibility of nine stakeholders by answering the question: How responsible do you think each of the following stakeholders is for protecting your safety and providing you with the resources you need to respond to the COVID-19 threat? For each of the nine stakeholders, participants answered the question using a 5-point Likert scale, from (1) "not responsible" to (5) "fully responsible".

Finally, Table 5 presents the items considered to represent the adoption of preventive behaviors associated with hygiene ( 7 items), social distancing ( 4 items), and informationseeking ( 3 items). The items were adapted and validated based on the study conducted by Cheng et al. [39]. Participants were asked to indicate the frequency with which they performed each of the fourteen preventive behaviors and were offered five response alternatives: (1) "never", (2) "rarely", (3) "sometimes", (4) "almost always", and (5) "always".

\subsection{Data Analysis}

We first ran descriptive analyses for the different scales and carried out internal consistency analysis through Cronbach's alpha coefficient ( $\alpha=$ Cronbach). Subsequently, gender-segregated averages and standard deviations to describe the sample were calculated.

Then, to evaluate potential differences between genders, a mean difference analysis was performed using Tukey's test for each of the items included in the study that characterize worry, risk perception, trust in the government, attribution of responsibility, and adoption of preventive behaviors. 
We used four ranges of family income and four ranges of participant age to facilitate the analyses (see Table 1). Similarly, the relationship variable considered two groups: with a partner (married or living with a partner) and without a partner (single, separated, or widowed).

Finally, a univariate factorial ANOVA was used to study the influence of gender on adopting COVID-19 preventive behaviors. First, for each participant, we calculated a single value associated with hygiene, social distancing, and information-seeking behaviors that corresponded to the average of the items related to these behaviors (see Table 5). Then, gender and its interaction with the remaining socioeconomic variables of the sample (age, income, and relationship status) were included as independent variables. Finally, we considered each of the calculated preventive behaviors (hygiene, social distancing, and information-seeking) as an independent variable.

\section{Results}

\subsection{Worry and Risk Perception}

Table 2 shows the mean values for worry and risk perception reported by men and women. When analyzing the levels of worry, women appear to report a significantly higher level of fear associated with COVID-19 $(p<0.05)$ than men. We found this for five of the six items used to characterize worry. Contrary to expectations, the results show no statistically significant differences between women's and men's perceptions of risk associated with COVID-19: that is, women and men perceived themselves to have the same probability of becoming infected, infecting others, and becoming seriously ill with COVID-19. It is interesting to note that for two of the three items considered to characterize risk perception (PR5 and PR6), both women and men reported a low risk perception (mean values below four on a 7-point scale).

Table 2. Mean values and standard deviation (SD) for each item measuring worry and risk perception of COVID-19.

\begin{tabular}{|c|c|c|c|c|c|}
\hline \multirow{2}{*}{\multicolumn{2}{|c|}{ Item Description }} & \multicolumn{2}{|c|}{ Female } & \multicolumn{2}{|c|}{ Male } \\
\hline & & Mean & SD & Mean & SD \\
\hline \multicolumn{6}{|c|}{ Worry $(\alpha=0.832)$} \\
\hline W1 & How afraid are you of contracting coronavirus (COVID-19)? & $4.58^{\mathrm{a}}$ & $(1.98)$ & $4.05^{\mathrm{b}}$ & $(2.07)$ \\
\hline W2 & How afraid are you of infecting someone you love with coronavirus (COVID-19)? & $6.28^{\mathrm{a}}$ & $(1.40)$ & $5.69^{\mathrm{b}}$ & $(1.88)$ \\
\hline W3 & How afraid are you of infecting others with coronavirus (COVID-19)? & $5.83^{\mathrm{a}}$ & $(1.58)$ & $5.09^{b}$ & $(1.94)$ \\
\hline W4 & $\begin{array}{l}\text { How concerned are you about the economic consequences of this Pandemic } \\
\text { (COVID-19) for you and your family? }\end{array}$ & $5.62^{\mathrm{a}}$ & $(1.67)$ & $5.71^{\mathrm{a}}$ & $(1.62)$ \\
\hline W5 & How afraid are you of losing your life to the coronavirus? & $4.69^{\mathrm{a}}$ & $(2.19)$ & $4.01^{\mathrm{b}}$ & $(2.37)$ \\
\hline W6 & I am worried about how this pandemic will evolve. & $5.89^{\mathrm{a}}$ & $(1.44)$ & $5.47^{\mathrm{b}}$ & $(1.68)$ \\
\hline \multicolumn{6}{|c|}{ Risk Perception $(\alpha=0.732)$} \\
\hline PR5 & $\begin{array}{l}\text { How likely are you to become infected with coronavirus (COVID-19) in the next } \\
\text { few months? }\end{array}$ & $3.72^{\mathrm{a}}$ & $(1.55)$ & $3.58^{\mathrm{a}}$ & $(1.61)$ \\
\hline PR6 & $\begin{array}{l}\text { How likely are you to become seriously ill from COVID-19 (e.g., be hospitalized in } \\
\text { the ICU, on a mechanical respirator, etc.) in the next few months? }\end{array}$ & $3.21^{\mathrm{a}}$ & $(1.60)$ & $3.07^{\mathrm{a}}$ & $(1.65)$ \\
\hline PR7 & $\begin{array}{l}\text { How likely is it that a Family Member or Friend of yours will become seriously ill } \\
\text { with COVID-19 (e.g., be hospitalized in the ICU, on a mechanical respirator, etc.) in } \\
\text { the next few months? }\end{array}$ & $4.50^{\mathrm{a}}$ & $(1.67)$ & $4.39^{\mathrm{a}}$ & $(1.62)$ \\
\hline
\end{tabular}

Mean values and standard deviations (SD) for each item. Mean values with distinct letters (a or b) between the female and male samples are significantly different at the $p<0.05$ level ( $t$-test). Items for worry were assessed on a 7-point Likert scale, from (1) "nothing" to (7) "very much". Similarly, items for risk perception were assessed on a 7-point Likert scale, from (1) "no risk" (7) "totally risky". Internal reliability was calculated for each scale ( $\alpha=$ Cronbach's alpha).

\subsection{Trust in Government}

Both women and men reported a low level of trust in the government (mean values below three on a 5-point scale for all items). However, compared to men, women exhibited the lowest levels of trust $(p<0.05)$ in the government, both in its competence to make decisions and solve problems associated with COVID-19, and in its integrity to maintain open and transparent communication, free from political or private pressures (see Table 3). 
Table 3. Mean values and standard deviation (SD) for each item measuring trust in government.

\begin{tabular}{|c|c|c|c|c|c|}
\hline \multirow{2}{*}{\multicolumn{2}{|c|}{ Item Description }} & \multicolumn{2}{|c|}{ Female } & \multicolumn{2}{|c|}{ Male } \\
\hline & & \multirow[t]{2}{*}{ Mean } & \multirow[t]{2}{*}{ SD } & \multirow[t]{2}{*}{ Mean } & \multirow[t]{2}{*}{ SD } \\
\hline Integrity & ased Trust $(\alpha=0.913)$ & & & & \\
\hline TR1 & $\begin{array}{l}\text { I feel confident that the government will provide all relevant information for the } \\
\text { health and safety of the public. }\end{array}$ & $2.12^{\mathrm{a}}$ & $(1.09)$ & $2.37^{b}$ & $(1.26)$ \\
\hline TR2 & $\begin{array}{l}\text { I am confident that the government will maintain open and transparent } \\
\text { communication with the public. }\end{array}$ & $2.03^{a}$ & $(1.09)$ & $2.30^{b}$ & $(1.25)$ \\
\hline TR3 & $\begin{array}{l}\text { I am confident that the government will act free of obligations or pressure from } \\
\text { political parties or private individuals. }\end{array}$ & $1.82^{\mathrm{a}}$ & $(0.99)$ & $1.90^{\mathrm{a}}$ & $(1.09)$ \\
\hline \multicolumn{6}{|c|}{ Competence-Based Trust $(\alpha=0.924)$} \\
\hline TR4 & $\begin{array}{l}\text { I feel confident that the government has the necessary competencies to make } \\
\text { good decisions. }\end{array}$ & $2.04^{\mathrm{a}}$ & $(1.07)$ & $2.28^{\mathrm{b}}$ & $(1.27)$ \\
\hline TR5 & $\begin{array}{l}\text { I feel confident that the government has the necessary competencies to resolve } \\
\text { possible problems. }\end{array}$ & $2.10^{\mathrm{a}}$ & $(1.09)$ & $2.30^{\mathrm{b}}$ & $(1.22)$ \\
\hline TR6 & $\begin{array}{l}\text { I feel confident that the government has the necessary competencies to adequately } \\
\text { communicate its associated risks. }\end{array}$ & $2.22^{\mathrm{a}}$ & (1.18) & $2.42^{b}$ & (1.23) \\
\hline
\end{tabular}

Mean values and standard deviations $(S D)$ for each item. Mean values with distinct letters (a or b) between the female and male samples are significantly different at the $p<0.05$ level ( $t$-test). Items were assessed on a 5-point Likert scale, from (1) "totally disagree" to (5) "totally agree". Internal reliability was calculated for each scale $(\alpha=$ Cronbach's alpha).

\subsection{Responsibility Attribution}

Our results show that, on average, both women and men stated that they themselves (RA1), their families (RA2), health personnel (RA7), the government (RA5), and municipalities (RA6) are primarily responsible for protecting their health and providing the resources needed to respond to the threat of COVID-19 (see Table 4). Similarly, both groups stated that those least responsible for protecting them from the pandemic are the Armed Forces (RA9), Chilean Police (RA8), their neighborhood community (RA4), and their friends and peers (RA4).

Table 4. Mean values and standard deviation (SD) for each item measuring responsibility attribution.

\begin{tabular}{|c|c|c|c|c|c|}
\hline \multirow{2}{*}{ Item Description } & & \multicolumn{2}{|c|}{ Female } & \multicolumn{2}{|c|}{ Male } \\
\hline & & Mean & SD & Mean & SD \\
\hline RA1 & You & $4.70^{\mathrm{a}}$ & $(0.57)$ & $4.62^{\mathrm{a}}$ & $(0.72)$ \\
\hline RA2 & Your family & $4.30^{\mathrm{a}}$ & $(0.86)$ & $4.21^{\mathrm{a}}$ & $(1.04)$ \\
\hline RA3 & Friends and/or colleagues & $3.44^{\mathrm{a}}$ & $(1.29)$ & $3.35^{\mathrm{a}}$ & (1.33) \\
\hline RA4 & Community/Neighborhood & $3.36^{\mathrm{a}}$ & $(1.32)$ & $3.10^{\mathrm{b}}$ & (1.36) \\
\hline RA5 & Government & $3.64^{\mathrm{a}}$ & $(1.39)$ & $3.51^{\mathrm{a}}$ & $(1.41)$ \\
\hline RA6 & Municipality/Mayor's Office & $3.68^{\mathrm{a}}$ & $(1.30)$ & $3.49^{b}$ & $(1.34)$ \\
\hline RA7 & Health Personnel & $4.16^{\mathrm{a}}$ & $(1.17)$ & $4.09^{\mathrm{a}}$ & (1.26) \\
\hline RA8 & Chilean Police & $3.13^{\mathrm{a}}$ & $(1.47)$ & $3.01^{\mathrm{a}}$ & (1.49) \\
\hline RA9 & Armed Forces (FFAA) & $3.04^{\mathrm{a}}$ & $(1.46)$ & $2.94^{\mathrm{a}}$ & (1.49) \\
\hline
\end{tabular}

Mean values and standard deviations (SD) for each item. Mean values with distinct letters (a or b) between the female and male samples are significantly different at the $p<0.05$ level ( $t$-test). Items were assessed on a 5-point Likert scale, from (1) "not responsible" to (5) "fully responsible".

It is worth noting that the mean values for all items related to attribution of responsibility were higher than 3 (on a 5-point scale). These findings suggest that participants perceived that all entities consulted have a significant level of responsibility for protecting them against the pandemic, regardless if these were institutions or individuals.

Table 4 shows no significant differences between women and men regarding attribution of responsibility, except regarding the burden attributed to municipalities (RA4) and the neighborhood community where each participant lived (RA6). However, in both cases, women assigned significantly $(p<0.05)$ more responsibility than men. 


\subsection{Preventive Behaviors}

Table 5 shows the mean values associated with the frequency of the adoption of preventive behaviors against COVID-19. Participants reported they always, or almost always, adopted behaviors to prevent the transmission and spread of the SARS-CoV-2 virus. In two preventive behaviors consulted, we found an average between 3 and 4 (on a 5 -point scale), indicating that these were behaviors performed sometimes or almost always. These corresponded to "I changed my clothes immediately upon arriving home after going out", and "I looked for updated information on the Ministry of Health figures".

Table 5. Mean values and standard deviation (SD) for each item measuring preventive behaviors of COVID-19.

\begin{tabular}{|c|c|c|c|c|c|}
\hline & \multirow{2}{*}{ Item Description } & \multicolumn{2}{|c|}{ Female } & \multicolumn{2}{|c|}{ Male } \\
\hline & & Mean & SD & Mean & SD \\
\hline \multicolumn{6}{|c|}{ Hygiene Behavior ( $\alpha=0.728)$} \\
\hline HB1 & $\begin{array}{l}\text { I wore a face covering on the street and in closed places } \\
\text { (supermarket, pharmacy, etc.). }\end{array}$ & $4.98^{\mathrm{a}}$ & $(0.18)$ & $4.92^{\mathrm{b}}$ & $(0.38)$ \\
\hline HB2 & $\begin{array}{l}\text { I disinfected the purchased products with bleach } \\
\text { or disinfectant. }\end{array}$ & $4.15^{\mathrm{a}}$ & $(1.17)$ & $4.01^{\mathrm{a}}$ & $(1.28)$ \\
\hline HB3 & $\begin{array}{l}\text { When I arrived home, I washed my hands with an } \\
\text { alcohol-based hand sanitizer or soap and water. }\end{array}$ & $4.89^{\mathrm{a}}$ & $(0.41)$ & $4.81^{\mathrm{b}}$ & $(0.57)$ \\
\hline HB4 & $\begin{array}{l}\text { I changed clothes immediately upon arriving home after } \\
\text { going out. }\end{array}$ & $3.51^{\mathrm{a}}$ & $(1.35)$ & $3.43^{\mathrm{a}}$ & $(1.40)$ \\
\hline HB5 & $\begin{array}{l}\text { I washed my hands with an alcohol-based hand } \\
\text { sanitizer after sneezing, coughing, or wiping my nose. }\end{array}$ & $4.17^{\mathrm{a}}$ & $(1.07)$ & $4.06^{\mathrm{a}}$ & $(1.17)$ \\
\hline HB6 & $\begin{array}{l}\text { When leaving my home, I avoided hugging, shaking } \\
\text { hands, or giving a kiss on the cheek when greeting } \\
\text { another person. }\end{array}$ & $4.72^{\mathrm{a}}$ & $(0.56)$ & $4.67^{\mathrm{a}}$ & $(0.76)$ \\
\hline HB7 & $\begin{array}{l}\text { When I left my home, I tried to keep a distance of at } \\
\text { least one meter from other people. }\end{array}$ & $4.74^{\mathrm{a}}$ & $(0.53)$ & $4.63^{b}$ & $(0.68)$ \\
\hline \multicolumn{6}{|c|}{ Lockdown Behavior $(\alpha=0.693)$} \\
\hline LB1 & $\begin{array}{l}\text { During this period, I avoided leaving my home and } \\
\text { being in contact with other people. }\end{array}$ & $4.67^{\mathrm{a}}$ & $(0.72)$ & $4.54^{\mathrm{b}}$ & $(0.90)$ \\
\hline LB2 & $\begin{array}{l}\text { During this period, I avoided going out to shop if I } \\
\text { could do it online. }\end{array}$ & $4.46^{\mathrm{a}}$ & $(0.91)$ & $4.30^{\mathrm{b}}$ & $(1.10)$ \\
\hline LB3 & $\begin{array}{l}\text { When I left home, I did so by using individual } \\
\text { temporary permits for essential activities. }\end{array}$ & $4.78^{\mathrm{a}}$ & $(0.65)$ & $4.70^{\mathrm{a}}$ & $(0.77)$ \\
\hline LB4 & $\begin{array}{l}\text { I avoided visits and holding or participating in social } \\
\text { events such as parties and meetings. }\end{array}$ & $4.87^{\mathrm{a}}$ & $(0.50)$ & $4.77^{\mathrm{b}}$ & $(0.69)$ \\
\hline \multicolumn{6}{|c|}{ Information-Seeking Behavior $(\alpha=0.734)$} \\
\hline ISB1 & $\begin{array}{l}\text { I was aware of the sanitary or isolation restrictions of } \\
\text { the territory where I live (mandatory quarantine, } \\
\text { sanitary cordon, curfew, etc.). }\end{array}$ & $4.70^{\mathrm{a}}$ & $(0.68)$ & $4.74^{\mathrm{a}}$ & $(0.63)$ \\
\hline ISB2 & $\begin{array}{l}\text { I was periodically informed of the national evolution of } \\
\text { the pandemic. }\end{array}$ & $3.96^{\mathrm{a}}$ & $(1.05)$ & $4.23^{b}$ & $(0.98)$ \\
\hline ISB3 & $\begin{array}{l}\text { I looked for updated information on the figures } \\
\text { provided by the Ministry of Health. }\end{array}$ & $3.37^{\mathrm{a}}$ & $(1.29)$ & $3.68^{b}$ & $(1.27)$ \\
\hline
\end{tabular}

Mean values and standard deviations $(S D)$ for each item. Mean values with distinct letters (a or b) between the female and male samples are significantly different at the $p<0.05$ level ( $t$-test). Items were rated on the following frequency scale: (1) "never", (2) "rarely", (3) "sometimes", (4) "almost always", and (5) "always". Internal reliability was calculated for each scale ( $\alpha=$ Cronbach's alpha).

Women reported adopting eight of the fourteen preventive behaviors consulted with a significantly higher frequency than men $(p<0.05)$. Thus, for hygiene behaviors, women report wearing a mask (HB1), washing their hands when arriving home (HB3), and keeping at least a one-meter distance from others (HB7) more frequently than men.

For behaviors associated with social distancing (whether in mandatory quarantine or non-quarantine periods), women reported avoiding going out (LB1 and LB2), and 
avoiding visits and participating in social events (LB4) more frequently than men $(p<0.05)$. Finally, in terms of the adoption of information-seeking behaviors, women reported being periodically informed of the national evolution of the pandemic (ISB2) and seeking updated information on the figures provided by the Ministry of Health (ISB3) with a significantly lower frequency than men.

\subsection{Factorial ANOVA}

To obtain a more comprehensive view of the influence of gender on the different groups of preventive behaviors, in the final step we performed a factorial ANOVA considering gender and its interactions with the remaining socioeconomic characteristics of the sample (age, income, and relationship status) as independent variables, and each of the preventive behaviors (hygiene, social distancing, and information seeking) as an independent variable.

Table 6 shows the factorial ANOVA results using a measure of hygiene behavior calculated as the average of the seven items associated with this behavior (items HB1 to HB7 in Table 5) as the independent variable. The model explained $6 \%$ of the variance $(\mathrm{F}=10,973.92 ; p=0.00)$. The results indicate that the groups formed by gender interacting with family income (G x FI) obtained significant differences in adopting hygiene behaviors. We found that women reported adopting preventive hygiene behaviors more frequently than men, and this frequency decreased as family income increased. Thus, lower-income women exhibited the highest frequency of preventive hygiene behaviors. We also found that higher-income men were less likely to adopt preventive hygiene behaviors to avoid the spread of COVID-19.

Table 6. Factorial ANOVA using gender and gender interaction with other socioeconomic characteristics as independent variables and each hygiene behavior as a dependent variable.

\begin{tabular}{cccc}
\hline \multirow{2}{*}{ Independent Variables } & \multicolumn{3}{c}{ Hygiene Behavior } \\
\cline { 2 - 4 } & MS & $\mathbf{F}$ & $p$-Value \\
\hline Intercept & 2946.90 & 10973.92 & 0.00 \\
Gender $(\mathrm{G})$ & 0.32 & 1.21 & 0.27 \\
G $\times$ PR & 0.01 & 0.05 & 0.95 \\
G $\times$ A & 0.58 & 2.14 & 0.07 \\
G $\times$ FI & 0.61 & 2.27 & 0.03 \\
G $\times$ A $\times$ PR & 0.18 & 0.67 & 0.61 \\
G $\times$ FI $\times$ PR & 0.58 & 2.17 & 0.04 \\
G $\times$ FI $\times$ A & 0.52 & 1.94 & 0.03 \\
Error & 0.27 & & \\
R2 & 0.06 & & \\
\hline
\end{tabular}

Mean square (MS), F-value (F) and p-value are shown for each interaction. The independent variables considered are gender $(\mathrm{G})$, partner relationship $(\mathrm{PR})$, age $(\mathrm{A})$, and family income (FI).

The three-way interaction between gender, family income, and partner relationship $(\mathrm{G} \times \mathrm{FI} \times \mathrm{PR})$ and gender, family income, and age $(\mathrm{G} \times \mathrm{FI} \times \mathrm{A})$ suggest significantly different levels in the frequency of the adoption of hygiene behaviors. However, these results were not conclusive trends to report.

The factorial ANOVA model using the adoption of social distancing preventive behaviors as the dependent variable did not show groups with significantly different levels in the frequency of adoption of social distancing preventive behaviors. In addition, we did not find significant results for the model using the adoption of information-seeking behaviors as the dependent variable.

\section{Discussion}

To better comprehend people's behavior in the face of the COVID-19 threat and thus contribute to the development of more effective risk communication strategies, the objective of this study was to understand gender differences in the various psychosocial factors 
that affect preventive behaviors against COVID-19. This study found three main results. First, women reported greater worry and fear of COVID-19 than men, and both men and women reported low personal risk perception. Second, men adopted preventive behaviors significantly less frequently than women. Finally, study participants reported a low degree of trust in government authorities, with women exhibiting the lowest trust levels.

In the context of preventive health behaviors, worry and fear are vital determinants [4]. Our results show that women reported the highest levels of worry and fear about the possibility of infection and spread of SARS-CoV-2, which is consistent with previous studies $[4,11,12,40,41]$. Ahmad et al. [12] argue that women's greater psychological vulnerability could explain this increased worry about pandemic outbreaks and higher stress levels. Also, women are more engaged in caregiving tasks, feeling responsible for themselves and their families, causing their levels of worry to increase [40,42]. Consistent with this argument, our results suggest that the more significant worry and fear reported by women is associated with the possibility of infecting the most relevant people around them. In turn, these results can also be explained by differences in knowledge related to the virus and its symptoms, as reported in previous studies [19], suggesting that women have a greater knowledge about the virus.

Previous studies have found differences between men and women concerning their perceptions of risk related to COVID-19 [4,11,12,40]. Our results indicate that both men and women reported a low-risk perception, with no significant differences according to the gender of the participant. That means that both groups maintained a similar perception of becoming infected, infecting others, and becoming seriously ill with COVID-19. The average age of the sample could explain this result: about $80 \%$ of the participants were between 18 and 29 years old. Previous studies show that the younger the person, the lower the risk perception of COVID-19 [4]. Also, since the beginning of the pandemic in late 2019, information from the WHO stated that young people were less likely to suffer severe effects from COVID-19, which we hypothesize may have lowered the risk perception of young adults.

On the other hand, the results show that they perceive a high risk for family members and significant others in their environment, which probably motivates them to adopt and maintain cautionary behaviors. This finding should be considered to design messages and other strategies that seek to promote these behaviors. Moreover, these findings are consistent with recommendations for experts that have highlighted the need to emphasize the collective nature of the pandemic and the need to protect others [43].

Similar to findings from previous studies [9,44-46], we found that women more frequently adopt various hygiene and social distancing behaviors. This difference can be explained by how both genders cope with the pandemic. Ahmad et al. [12] noted that women are more problem-focused in dealing with the pandemic, while men are less active in seeking solutions to mitigate the risks of COVID-19. This can also be the result of the higher levels of worry and fear reported by women, a situation that induces a greater intention to adopt preventive behaviors [47]. Additional studies suggest that social norms related to the caregiver role, usually taken by women, may influence the greater adoption of cautionary behaviors reported. In general, women carry out hygiene behaviors more frequently [48] and tend to seek medical help more quickly when faced with a health concern [49]. A recent study conducted in Canada analyzing cases of COVID-19 showed that it was women who sought testing promptly to determine whether they were infected by the virus [50].

Furthermore, we have found a decrease in the adoption of preventive measures as family income increases, especially in men. Chile has a high level of socioeconomic inequality that influences health outcomes [51]. In a recent study conducted in Santiago, Chile, a strong association was found between socio-economic status and COVID-19 outcomes [51]. Infection fatality rates in young people and COVID-19-attributed deaths have been significantly higher in low-income municipalities [51]. Moreover, higher-income individuals can access better public health care close to their households and can also 
finance private health providers, allowing them to go directly to specialized professionals when needed [52]. As a result, they could have a greater sense of security and confidence in the health care system and a higher quality health care if they were to become infected with the virus. Chan et al. [53] found that a high level of confidence in the health care system combined with low trust in government significantly reduces the level of cooperation and compliance with government preventive measures. If you add that men tend to have a lower risk perception of COVID-19 than women [10], it is no surprise that our results show that higher-income men were the least likely to adopt preventive behaviors.

Trust in government institutions is essential to influence people's risk perceptions and to motivate the adoption of preventive measures against COVID-19. Our results indicate that participants report a low level of trust in government authorities, both in integritybased and competence-based trust. The level of trust among women was significantly lower than that reported by men, in alignment with results that have been reported in other parts of the world [14]. Women's lower confidence in the integrity of the government and its competence to cope with this crisis may be due to their greater worry and fear of contagion and the consequences of contracting COVID-19, and their harsher evaluation of the performance of the government. Interestingly, despite this low confidence, women seem to adopt more preventive measures. However, our results also indicate that females appear to attribute the responsibility to themselves for adopting these behaviors. Consequently, they may continue to do so, despite their low levels of trust, since they perceive themselves as being responsible for taking care of themselves and others. However, this low trust in the authorities may influence their behaviors as the health crisis continues. Therefore, if actions are not implemented, this low trust will negatively impact the continuation of these behaviors, and the number of those who become ill will increase [54].

\section{Implications}

Our results indicate that participants, particularly women, report low levels of trust in government authorities, which has important implications for the design and implementation of programs, plans, and strategies to encourage the adoption of COVID-19 preventive behaviors. Trust in authorities has been considered one of the main factors influencing the perception of risk and the adoption of preventive behaviors to cope with the COVID-19 pandemic [12]. Moreover, recent studies have concluded that non-compliance with preventive measures is strongly associated with low trust in the authorities [13]. To achieve more effective risk communication strategies for the motivation and adoption of preventive behaviors, future communication campaigns should foster trust in authorities or be associated with people who enjoy the trust of the public to disseminate risk information [13].

In addition to adopting preventive behaviors significantly less frequently than women, men reported lower levels of worry and fear of COVID-19 than that expressed by women. These results have implications for those in charge of designing and implementing COVID19 prevention plans and programs, especially considering that men are almost three times more likely to be admitted to an intensive care unit and more likely to die from COVID$19[5,10]$.

Thus, to increase the effectiveness of the messages and the consequent adoption of preventive behaviors, gender should be taken in account in risk communication campaigns. The same messages and strategies cannot be used for both women and men. For example, campaigns targeted to women could be aimed at increasing trust in authorities; whereas those targeted to men should be aimed at incentivizing preventive behaviors. Moreover, specific gender characteristics could be considered in the design of these messages. For instance, Howard [16] suggested that interventions to increase the use of face masks in men should focus on the notion of strength, which could be achieved by emphasizing the role of protector of the family. 


\section{Conclusions and Limitations}

Our results confirm significant gender differences in the psychosocial factors that influence the adoption of preventive behaviors against COVID-19. We conclude that women report higher levels of worry and fear of the COVID-19 pandemic and more actively adopt preventive hygiene and social distancing behaviors than men. Similarly, we conclude that the participants in this study report a low level of trust in government authorities and that women report a lower level of trust than men.

Finally, we conclude that gender plays an important role, and must be considered in the future design of risk communication plans, programs, and strategies if the objective is to yield more effective results in controlling a pandemic such as COVID-19. In particular, considering the higher probability of mortality and morbidity of men from COVID-19, the lower worry and fear declared by men, in addition to their adopting preventive behaviors less frequently than women, we suggest that future risk communication campaigns incorporate gender-based differences for the target audience and attempt to sensitize the male population to the seriousness of the pandemic and its effects.

We must acknowledge the limitations of the present study. First, we have used crosssectional data, which prevents us from generalizing our results and infer causality. Second, given that our sample consisted of undergraduate and graduate students, we should be careful in generalizing these results to the general population. In the future, longitudinal studies with a more socioeconomically representative sample could be used to provide more robust and generalizable results to confirm the influence of gender on adopting preventive behaviors.

Author Contributions: Conceptualization, N.B. and P.C. (Paola Cordón); methodology, N.B. and P.C. (Pamela Cisternas); software, P.C. (Pamela Cisternas); validation, P.C. (Pamela Cisternas) and N.B.; formal analysis, P.C. (Pamela Cisternas).; investigation, N.B., P.C. (Paola Cordón), J.C. and P.R.; resources, N.B. and P.R.; data curation, P.C. (Pamela Cisternas); writing-original draft preparation, N.B., P.C. (Paola Cordón), J.C. and P.R.; writing-review and editing, N.B., P.C. (Paola Cordón), J.C. and P.R.; visualization, P.C. (Paola Cordón), P.C. (Pamela Cisternas) and J.C.; supervision, N.B. and P.R.; project administration, N.B. and P.R.; funding acquisition, N.B. and P.R. All authors have read and agreed to the published version of the manuscript.

Funding: This research was partially funded by the National Research and Development Agency (ANID) of the Ministry of Science, Technology, Knowledge and Innovation of Chile through the National Fund for Scientific and Technological Research (Fondecyt, Grant 1180996) and by the Research Center for Integrated Disaster Risk Management (CIGIDEN), ANID/FONDAP/15110017.

Institutional Review Board Statement: The study was conducted according to the guidelines of the Declaration of Helsinki, and approved by the Ethics Committee of Universidad Andrés Bello (Approval act 023, 12 August 2020).

Informed Consent Statement: Informed consent was obtained from all subjects involved in the study.

Data Availability Statement: Data sharing not applicable.

Conflicts of Interest: The authors declare no conflict of interest.

\section{References}

1. World Health Organization. Coronavirus Disease (COVID-19) Dashboard. Available online: https://covid19.who.int/ (accessed on 24 February 2021).

2. World Bank. COVID-19 to Plunge Global Economy into Worst Recession since World War II. Available online: https: / / www.worldbank.org/en/news/press-release/2020/06/08/covid-19-to-plunge-global-economy-into-worst-recessionsince-world-war-ii (accessed on 30 March 2021).

3. Josa-Laorden, C.; Crestelo-Vieitez, A.; García Andreu, M.d.M.; Rubio-Rivas, M.; Sánchez, M.; Toledo Samaniego, N.; Arnalich Fernández, F.; Iguaran Bermudez, R.; Fonseca Aizpuru, E.M.; Vargas Núnez, J.A. Gender-Based Differences by Age Range in Patients Hospitalized with COVID-19: A Spanish Observational Cohort Study. J. Clin. Med. 2021, 10, 899. [CrossRef]

4. Barber, S.J.; Kim, H. COVID-19 worries and behavior changes in older and younger men and women. J. Gerontol. Ser. B 2021, 76, e17-e23. [CrossRef] [PubMed] 
5. Peckham, H.; de Gruijter, N.M.; Raine, C.; Radziszewska, A.; Ciurtin, C.; Wedderburn, L.R.; Rosser, E.C.; Webb, K.; Deakin, C.T. Male sex identified by global COVID-19 meta-analysis as a risk factor for death and ITU admission. Nat. Commun. 2020, 11, 1-10. [CrossRef]

6. Bwire, G.M. Coronavirus: Why men are more vulnerable to Covid-19 than women? SN Compr. Clin. Med. 2020, 2, 874-876. [CrossRef]

7. Dehingia, N.; Raj, A. Sex differences in COVID-19 case fatality: Do we know enough? Lancet Glob. Health 2021, 9, e14-e15. [CrossRef]

8. Griffith, D.M.; Sharma, G.; Holliday, C.S.; Enyia, O.K.; Valliere, M.; Semlow, A.R.; Stewart, E.C.; Blumenthal, R.S. Men and COVID-19: A Biopsychosocial Approach to Understanding Sex Differences in Mortality and Recommendations for Practice and Policy Interventions. Prev Chronic Dis. 2020, 17, E63. [CrossRef]

9. Galasso, V.; Pons, V.; Profeta, P.; Becher, M.; Brouard, S.; Foucault, M. Gender differences in COVID-19 attitudes and behavior: Panel evidence from eight countries. Proc. Natl. Acad. Sci. USA 2020, 117, 27285-27291. [CrossRef]

10. Rana, I.A.; Bhatti, S.S.; Aslam, A.B.; Jamshed, A.; Ahmed, J.; Shah, A.A. COVID-19 risk perception and coping mechanisms: Does gender make a difference? Int. J. Disaster Risk Reduct. 2021, 55, 102096. [CrossRef] [PubMed]

11. Niño, M.; Harris, C.; Drawve, G.; Fitzpatrick, K.M. Race and ethnicity, gender, and age on perceived threats and fear of COVID-19: Evidence from two national data sources. SSM-Popul. Health 2021, 13, 100717. [CrossRef] [PubMed]

12. Ahmad, M.; Iram, K.; Jabeen, G. Perception-based influence factors of intention to adopt COVID-19 epidemic prevention in China. Environ. Res. 2020, 190, 109995. [CrossRef]

13. Nivette, A.; Ribeaud, D.; Murray, A.; Steinhoff, A.; Bechtiger, L.; Hepp, U.; Shanahan, L.; Eisner, M. Non-compliance with COVID-19-related public health measures among young adults in Switzerland: Insights from a longitudinal cohort study. Soc. Sci. Med. 2021, 268, 113370. [CrossRef] [PubMed]

14. Rieger, M.O.; Wang, M. Trust in Government Actions during the COVID-19 Crisis. 2020. Available online: https://www.uni-trier. $\mathrm{de} /$ fileadmin/fb4/prof/BWL/FIN/Files/Trust_in_Government_Actions_during_the_COVID-19_Crisis.pdf (accessed on 15 January 2021).

15. Mellström, U. COVID-19, masculinity and risk/at risk. Int. J. Masc. Stud. 2020, 15, 94-96. [CrossRef]

16. Howard, M.C. Gender, face mask perceptions, and face mask wearing: Are men being dangerous during the COVID-19 pandemic? Pers. Individ. Differ. 2021, 170, 110417. [CrossRef]

17. Baker, P.; White, A.; Morgan, R. Men's health: COVID-19 pandemic highlights need for overdue policy action. Lancet 2020, 395, 1886-1888. [CrossRef]

18. Smith, J.; Griffith, D.; White, A.; Baker, P.; Watkins, D.; Drummond, M.; Semlow, A. COVID-19, Equity and Men's Health. Int. J. Mens Soc. Community Health 2020, 3, e48-e64. [CrossRef]

19. Pinchoff, J.; Santhya, K.; White, C.; Rampal, S.; Acharya, R.; Ngo, T.D. Gender specific differences in COVID-19 knowledge, behavior and health effects among adolescents and young adults in Uttar Pradesh and Bihar, India. PLoS ONE 2020, 15, e0244053. [CrossRef]

20. Bronfman, N.C.; Cisternas, P.C.; Repetto, P.B.; Castañeda, J.V. Natural disaster preparedness in a multi-hazard environment: Characterizing the sociodemographic profile of those better (worse) prepared. PLoS ONE 2019, 14, e0214249. [CrossRef]

21. Kohn, S.; Eaton, J.L.; Feroz, S.; Bainbridge, A.A.; Hoolachan, J.; Barnett, D.J. Personal disaster preparedness: An integrative review of the literature. Disaster Med. Public Health Prep. 2012, 6, 217-231. [CrossRef]

22. Bateman, J.M.; Edwards, B. Gender and evacuation: A closer look at why women are more likely to evacuate for hurricanes. Nat. Hazards Rev. 2002, 3, 107-117. [CrossRef]

23. Kung, Y.W.; Chen, S.H. Perception of Earthquake Risk in Taiwan: Effects of Gender and Past Earthquake Experience. Risk Anal. 2012, 32, 1535-1546. [CrossRef]

24. Terpstra, T. Emotions, trust, and perceived risk: Affective and cognitive routes to flood preparedness behavior. Risk Anal. 2011, 31, 1658-1675. [CrossRef]

25. Onuma, H.; Shin, K.J.; Managi, S. Household preparedness for natural disasters: Impact of disaster experience and implications for future disaster risks in Japan. Int. J. Disaster Risk Reduct. 2017, 21, 148-158. [CrossRef]

26. Castañeda, J.V.; Bronfman, N.C.; Cisternas, P.C.; Repetto, P.B. Understanding the culture of natural disaster preparedness: Exploring the effect of experience and sociodemographic predictors. Nat. Hazards 2020, 103, 1881-1904. [CrossRef]

27. McCright, A.M. The effects of gender on climate change knowledge and concern in the American public. Popul. Environ. 2010, 32, 66-87. [CrossRef]

28. Neumayer, E.; Plümper, T. The gendered nature of natural disasters: The impact of catastrophic events on the gender gap in life expectancy, 1981-2002. Ann. Assoc. Am. Geogr. 2007, 97, 551-566. [CrossRef]

29. Hung, L.-S. Gender, intra-household dynamics, and household hurricane preparedness: An exploratory study employing a dyadic interview approach. Int. J. Disaster Risk Sci. 2018, 9, 16-27. [CrossRef]

30. Tyler, M.; Fairbrother, P. Gender, households, and decision-making for wildfire safety. Disasters 2018, 42, 697-718. [CrossRef]

31. Rickard, L.N.; Yang, Z.J.; Schuldt, J.P.; Eosco, G.M.; Scherer, C.W.; Daziano, R.A. Sizing up a superstorm: Exploring the role of recalled experience and attribution of responsibility in judgments of future hurricane risk. Risk Anal. 2017, 37, 2334-2349. [CrossRef] [PubMed] 
32. Bronfman, N.C.; Cisternas, P.C.; Repetto, P.B.; Castañeda, J.V.; Guic, E. Understanding the relationship between direct experience and risk perception of natural hazards. Risk Anal. 2020, 40, 2057-2070. [CrossRef]

33. Weinstein, N.D.; Lyon, J.E.; Rothman, A.J.; Cuite, C.L. Preoccupation and affect as predictors of protective action following natural disaster. Br. J. Health Psychol. 2000, 5, 351-363. [CrossRef]

34. Arias, J.P.; Bronfman, N.C.; Cisternas, P.C.; Repetto, P.B. Hazard proximity and risk perception of tsunamis in coastal cities: Are people able to identify their risk? PLoS ONE 2017, 12, e0186455. [CrossRef]

35. Lindell, M.K.; Arlikatti, S.; Prater, C.S. Why people do what they do to protect against earthquake risk: Perceptions of hazard adjustment attributes. Risk Anal. 2009, 29, 1072-1088. [CrossRef]

36. Renn, O.; Levine, D. Credibility and trust in risk communication. In Communicating Risks to the Public; Springer: Berlin/Heidelberg, Germany, 1991; pp. 175-217.

37. Bronfman, N.C.; Jiménez, R.B.; Arévalo, P.C.; Cifuentes, L.A. Understanding social acceptance of electricity generation sources. Energy Policy 2012, 46, 246-252. [CrossRef]

38. Bronfman, N.C.; Cisternas, P.C.; López-Vázquez, E.; Cifuentes, L.A. Trust and risk perception of natural hazards: Implications for risk preparedness in Chile. Nat. Hazards 2016, 81, 307-327. [CrossRef]

39. Cheng, C.; Ng, A.K. Psychosocial factors predicting SARS-preventive behaviors in four major SARS-affected regions. J. Appl. Soc. Psychol. 2006, 36, 222-247. [CrossRef]

40. Broche-Pérez, Y.; Fernández-Fleites, Z.; Jiménez-Puig, E.; Fernández-Castillo, E.; Rodríguez-Martin, B.C. Gender and fear of COVID-19 in a Cuban population sample. Int. J. Ment. Health Addict. 2020, 1-9. [CrossRef] [PubMed]

41. Reznik, A.; Gritsenko, V.; Konstantinov, V.; Khamenka, N.; Isralowitz, R. COVID-19 fear in Eastern Europe: Validation of the fear of COVID-19 scale. Int. J. Ment. Health Addict. 2020, 1-6. [CrossRef] [PubMed]

42. Xiong, J.; Lipsitz, O.; Nasri, F.; Lui, L.M.; Gill, H.; Phan, L.; Chen-Li, D.; Iacobucci, M.; Ho, R.; Majeed, A. Impact of COVID-19 pandemic on mental health in the general population: A systematic review. J. Affect. Disord. 2020, 277, 55-64. [CrossRef] [PubMed]

43. Bonell, C.; Michie, S.; Reicher, S.; West, R.; Bear, L.; Yardley, L.; Curtis, V.; Amlôt, R.; Rubin, G.J. Harnessing behavioural science in public health campaigns to maintain 'social distancing' in response to the COVID-19 pandemic: Key principles. J. Epidemiol. Community Health 2020, 74, 617-619.

44. Raude, J.; Lecrique, J.-M.; Lasbeur, L.; Leon, C.; Guignard, R.; Roscoät, E.D.; Arwidson, P. Determinants of preventive behaviors in response to the COVID-19 pandemic in France: Comparing the sociocultural, psychosocial and social cognitive explanations. Front. Psychol. 2020, 11, 3345. [CrossRef]

45. Barile, J.P.; Guerin, R.J.; Fisher, K.A.; Tian, L.H.; Okun, A.H.; Vanden Esschert, K.L.; Jeffers, A.; Gurbaxani, B.M.; Thompson, W.W.; Prue, C.E. Theory-based Behavioral Predictors of Self-reported Use of Face Coverings in Public Settings during the COVID-19 Pandemic in the United States. Ann. Behav. Med. 2021, 55, 82-88. [CrossRef]

46. Brouard, S.; Vasilopoulos, P.; Becher, M. Sociodemographic and psychological correlates of compliance with the Covid-19 public health measures in France. Can. J. Political Sci. 2020, 53, 253-258. [CrossRef]

47. Harper, C.A.; Satchell, L.P.; Fido, D.; Latzman, R.D. Functional fear predicts public health compliance in the COVID-19 pandemic. Int. J. Ment. Health Addict. 2020, 1-14. [CrossRef]

48. Johnson, H.D.; Sholcosky, D.; Gabello, K.; Ragni, R.; Ogonosky, N. Sex differences in public restroom handwashing behavior associated with visual behavior prompts. Percept. Mot. Ski. 2003, 97, 805-810. [CrossRef]

49. Thompson, A.E.; Anisimowicz, Y.; Miedema, B.; Hogg, W.; Wodchis, W.P.; Aubrey-Bassler, K. The influence of gender and other patient characteristics on health care-seeking behaviour: A QUALICOPC study. BMC Fam. Pract. 2016, 17, 1-7. [CrossRef] [PubMed]

50. Joh, E.; Buchan, S.A.; Daneman, N.; Paul, L.A.; Brown, K.A. Factors Associated with Timely Test Seeking, Test Turnaround, and Public Reporting of COVID-19: A retrospective analysis in Ontario, Canada. medRxiv 2021. [CrossRef]

51. Mena, G.E.; Martinez, P.P.; Mahmud, A.S.; Marquet, P.A.; Buckee, C.O.; Santillana, M. Socioeconomic status determines COVID-19 incidence and related mortality in Santiago, Chile. Science 2021, 372, abg5298. [CrossRef] [PubMed]

52. Rotarou, E.S.; Sakellariou, D. Determinants of utilisation rates of preventive health services: Evidence from Chile. BMC Public Health 2018, 18, 1-11. [CrossRef] [PubMed]

53. Chan, H.F.; Brumpton, M.; Macintyre, A.; Arapoc, J.; Savage, D.A.; Skali, A.; Stadelmann, D.; Torgler, B. How confidence in health care systems affects mobility and compliance during the COVID-19 pandemic. PLoS ONE 2020, 15, e0240644. [CrossRef] [PubMed]

54. Fancourt, D.; Steptoe, A.; Wright, L. The Cummings effect: Politics, trust, and behaviours during the COVID-19 pandemic. Lancet 2020, 396, 464-465. [CrossRef] 